Asylum

\section{US cancer researcher in Moscow}

Washington

To the astonishment of his former coworkers, Arnold Lockshin appeared on Soviet television last week saying that he had defected from the West. Lockshin had been on the staff of the Stehlin Foundation for Cancer Research in Houston, Texas, until he was fired on 19 August. Stehlin officials say Lockshin was dismissed because of poor job performance.

Lockshin was awarded a doctorate in biochemistry from the University of Wisconsin in 1966. His dissertation research was on photosynthesis. After moving to the Boston area he collaborated with Lawrence Bogorad at Harvard on work on chloroplasts. He became involved in cancer research while working at the University of Southern California. In the early 1980s, he joined the Stehlin Foundation, working chiefly on the effects of various cancer therapies on human tumours expressed in nude mice. He is the senior author of 20 scientific articles.

Most recently, Lockshin has been concerned to set up animal models for the study of the mechanism of immunosuppression by cyclosporin $\mathrm{A}$, and the formation of tumours as a consequence. Some of Lockshin's recent work in this field was submitted for publication in Nature earlier in the summer. Colleagues in Texas say that the letter saying that the article concerned would be more suitably placed in a specialist journal arrived in Houston the day that Lockshin was fired.

The laboratory director of the Stehlin Foundation, Beppino Giovanella, says that Lockshin gave no indication of his intention to defect, but he acknowledges that Lockshin's political views were "not exactly right wing". Robert Burris, Lockshin's graduate adviser at Wisconsin, says Lockshin visited Cuba while a graduate student. First reports from Moscow had Lockshin's name spelled Lokshin, causing

confusion about his identity.

Lockshin's own account of his defection is somewhat different. He said on television that since the time of the Vietnam war he and his wife had been active in "the anti-war movement, the movement for peace and for changes in the social policies of the United States". As a result, he claimed, he and his family suffered "endless threats by telephone and letter", and also "pogroms" against his laboratory and apartment. His dismissal, he said, was on political grounds. He hopes to resume his research work, in the Soviet Union, he said, in due course.

In back-up interviews on the foreign services of Soviet radio, Lockshin amplified his story. His latest political action, he said, was a demonstration in Houston against President Reagan's Strategic Defense Initiative. The threats against his wife included, he said, an "ex-green-beret waving a gun in her face", while he himself had been threatened with "physical annihilation". The US "political police", he alleged, had intercepted his mail, tapped his telephone calls and generally orchestrated the campaign of harassment and denigration.

The Soviet media, not surprisingly, made the most of the incident, particularly as it came just before the Reykjavik minisummit. Some commentators, however, clearly over-reacted - Aleksandr Barabeichik of Moscow Radio's "World Service" construed the fact that the Americans had failed to identify Lockshin (because of the misspelling of his name) as "a kind of sociological warfare". And none of the commentators mentioned the fact that, in spite of the alleged harassment, Lockshin was able to contact the Soviet Embassy in Washington, arrange his political asylum and book flights to Moscow for himself, his wife and three children without let or hindrance. Joseph Palca \& Vera Rich

\section{"Extinct" lemurs found in Madagascar}

\section{Washington}

A GROUP of about 35 greater bamboo lemurs (Hapalemur simus), feared to have been extinct since the early $1970 \mathrm{~s}$, has been found in a remote rainforest in southeastern Madagascar.

The animals were discovered by Patricia Wright of Duke University during a recent expedition. The fate of the species is far from assured, however, because unless there are other surviving groups, the genetic variation present may be too low for recovery.

Furthermore, the animals, which feed on bamboo, are not found in any of the 11 wildlife reserves on the island. Efforts are
British research

\section{Better measures of decline}

THE Advisory Board for the Research Councils (ABRC), interposed between the grant-making research councils and the British government, should now be better placed to chart the decline of British basic science. That seems to be the chief message of two reports commissioned by the advisory board and published this week

An account of the findings of the first report prepared by its authors, Ben Martin of the Science Policy Research Unit at the University of Sussex and John Irvine of the Technical Change Centre in London, appears in this issue on page 591.

The second document, the result of research by the Science and Engineering Policy Studies Unit, jointly run by the Royal Society and the Fellowship of Engineering, consists of a detailed comparison of the productivity of various countries in some specific fields of research. An extended summary of that document by its authors will appear in next week's Nature.

The publication of the two reports is something of a landmark for ABRC, whose activities have been traditionally confined to advising the British government on the proper division of the research budget among its potential recipients.

Although this advice has been published on some occasions, $\mathrm{ABRC}$ has not previously commissioned and published studies of particular aspects of British administration although its predecessor, the Council for Science Policy (disbanded after the Rothschild report of 1971) regularly undertook studies of the administration of science. ABRC now confidently labels its document "No.1", and promises that there will be more to follow.

To some extent, the studies now published overlap. Each, for example, is concerned with the scale of government spending on civil science; each concludes that, by different yardsticks, Britain lags behind its industrial competitors in Western Europe as well as Japan and the United States.

The Royal Society document is chiefly concerned to test the applicability of "bibliometric indices", citation indices and the like, as measures of the output of research. Interestingly, these techniques have been zealously applied to a number of research fields in which British scientists are active by the authors of the first report, Martin and Irvine.

Even though cautioulsy, the authors of the Royal Society report conclude that bibliometric analysis is a useful measure of a research community's standing relative to others. 